\title{
Chapter 20 \\ Comparison of Radioactivity Release and Contamination from the Fukushima and Chernobyl Nuclear Power Plant Accidents
}

\author{
Tetsuji Imanaka
}

\begin{abstract}
Although both the Fukushima Daiichi Nuclear Power Plant (FNPP) accident in 2011 and the Chernobyl NPP Unit 4 (CNPP) accident in 1986 are classified as Level 7, the worst nuclear incidence on the International Nuclear and Radiological Event Scale by the International Atomic Energy Agency, there are various differences between the two, including the accident process, released radionuclide composition, and meteorological and geological conditions. The amounts of iodine-131 $\left({ }^{131} \mathrm{I}\right)$ and cesium-137 $\left({ }^{137} \mathrm{Cs}\right)$ released into the atmosphere were about six times smaller after the FNPP accident compared to the CNPP accident. Cesium-137 is the most important radionuclide in considering long-term effects of nuclear accidents. According to Chernobyl laws in Ukraine, Belarus and Russia, depending on the level of ${ }^{137} \mathrm{Cs}$ contamination, the contaminated territories were classified as alienation zone $\left(>1480 \mathrm{kBq} \mathrm{m}^{-2}\right)$, obligatory resettlement zone $\left(555-1480 \mathrm{kBq} \mathrm{m}^{-2}\right)$ and voluntarily resettlement zone $\left(185-555 \mathrm{kBq} \mathrm{m}^{-2}\right)$. The areas of the corresponding zones around FNPP were 272, 459 and $1405 \mathrm{~km}^{2}$, respectively, which were 11-15 times smaller compared to the CNPP accident. Meanwhile, the number of affected people around FNPP was only three to five times smaller compared to CNPP, reflecting the higher population density for the FNPP accient. Cumulative exposures for the 1 st year $1 \mathrm{~m}$ above ground (normalized to the initial ${ }^{137} \mathrm{Cs}$ deposition of $1 \mathrm{MBq} \mathrm{m}^{-2}$ ) were $63 \mathrm{mGy}$ for the FNPP accident, while it was $500 \mathrm{mGy}$ for the CNPP accident because more various radionuclides were emitted in case of the CNPP accident than the FNPP accident. Cumulative exposures at 30 years were evaluated to be $500 \mathrm{mGy}$ and $970 \mathrm{mGy}$ for the FNPP accident and the CNPP accident, respectively.
\end{abstract}

Keywords Fukushima Daiichi Nuclear Power Plant accident · The Chernobyl accident $\cdot$ Radioactivity release $\cdot$ Radioactive contamination $\cdot$ Cesium-137

T. Imanaka $(\bowtie)$

Institute for Integrated Radiation and Nuclear Science, Kyoto University, Kumatori, Sennan,

Osaka, Japan

e-mail: imanaka@ rri.kyoto-u.ac.jp 


\subsection{Introduction}

Both the Fukushima Daiichi Nuclear Power Plant (FNPP) accident in 2011 and the Chernobyl NPP Unit 4 (CNPP) accident in 1986 are classified as Level 7, which is the highest level on the International Nuclear and Radiological Event Scale (INES) as defined by the International Atomic Energy Agency (IAEA) [1, 2]. In both accidents, a large amount of radionuclides were released into the environment from the damaged reactors and large areas of land were heavily contaminated to the extent that many people have to be evacuated for a long period [3-5]. Although it is clear that each accident had a big impact on society, they were different in various aspects, including the accident process, composition of radioactive contamination and geological conditions $[6,7]$.

FNPP was the first nuclear power plant built by the Tokyo Electric Power Company (TEPCO) and its first unit (Unit 1: $460 \mathrm{MWe}$ ) began operation in 1971. By 2011, FNPP had six boiling water reactor (BWR) units (Units 2-5: $780 \mathrm{MWe}$; Unit 6: $1100 \mathrm{MWe}$ ) developed by General Electric (GE, USA). Units 4, 5 and 6 were out of operation at the time of the earthquake $(14: 46$ March 11, 2011) due to annual maintenance work, while Units 1, 2 and 3 were operating at full power [8, 9].

The epicenter of the Great East Japan Earthquake was approximately $180 \mathrm{~km}$ away from FNPP. At 14:47, the three operating reactors were automatically shut down due to a large seismic acceleration, and emergency diesel generators (EDGs) were then activated to provide necessary electricity to the station. The tsunami waves, at over $10 \mathrm{~m}$ high, arrived at FNPP around 15:36 and flooded the basement of the turbine buildings where EDGs were located. EDG failure resulted in power loss for the pumps providing coolant water to remove decay heat from the reactor cores, which was the real emergency that led to the FNPP accident.

Several emergency cooling systems that do not require electric power were installed at each BWR in the event of a power outage. These cooling systems included isolation condenser (IC) systems, reactor core isolation cooling (RCIC) systems and high-pressure coolant injection (HPCI) systems. Unit 1 was equipped with IC and HPCI, while Units 2 and 3 were equipped with RCIC and HPCI. These emergency cooling systems were not designed to work for a long period, and consequently three FNPP reactors operating at the time of the tsunami became damaged one by one. The sequence of reactor damage is summarized below [10]:

- Unit 1: After EDG power failure, both IC and HPCI systems lost function. Without emergency cooling, the reactor core began meltdown, and fuel melted through the reactor pressure vessel (RPV) in the evening of March 11. At 02:30 March 12, the drywell (DW) inner pressure was measured to be $840 \mathrm{kPa}$, about twice the maximum design pressure of $427 \mathrm{kPa}$. To avoid rupture of $\mathrm{DW}$, the operator tried to vent the pressure, successfully releasing pressure to the acceptable level at 14:30. At 15:36 March 12, however, a hydrogen explosion occurred at the roof of the reactor building, which was strong enough to destroy the roof and the wall on the highest floor of the reactor building. 
- Unit 3: After power loss, RCIC remained functional until 11:36 March 12, and then HPCI was automatically actuated. In the early morning on March 13, the Unit 3 operator decided to switch the cooling system from HPCI to the line using fire engine water prepared outside the building. However, the cooling systems were not switched quickly, which left the reactor without a cooling supply for about $7 \mathrm{~h}$. The meltdown and melt-through process of Unit 3 began in the morning on March 13 and subsequently worsened. A hydrogen explosion occurred at 11:01 March 14.

- Unit 2: After power loss, RCIC remained functional until 13:25 March 14. The Unit 2 operator attempted a change of cooling system to fire engines, but was unable to switch systems quickly, leaving the reactor without a cooling supply for about $2 \mathrm{~h}$. The meltdown and melt-through process of Unit 2 began in the evening on March 14. A high DW pressure was observed that night, and an attempted venting operation was unsuccessful. In the morning on March 15, a sudden drop of DW pressure was observed, which suggested containment rupture and massive release of radioactivity into the atmosphere.

In this paper, we compare the radiological consequences between the FNPP accident and the CNPP accident with respect to the amount of radioactivity released into the atmosphere and the radioactive contamination on land.

\subsection{Radioactivity Release}

A gradual increase in radiation levels was observed at the entrance gate of FNPP beginning 04:00 March 12. Radioactivity release from the Unit 1 reactor building began early in the morning of March 12. The first large release occurred as a result of the Unit 1 vent operation at 14:30 March 12, followed by the hydrogen explosion at 15:36. Unit 3 began to release radioactivity in the morning on March 13. Serious radioactivity release from Unit 2 occurred from the evening of March 14 to the morning of March 15. Significant radioactivity release into the atmosphere continued up to the end of March.

The amount of radionuclides released into the environment is the basic information required to consider the scale of nuclear accidents. To date, two methods have been applied to estimate the amount of radionuclides released by the FNPP accident. The first method is a computer simulation of the accident process. This method requires many assumptions about the parameters used in the simulation, which increases uncertainty in the results $[11,12]$. The second method is based on an inversion technique that combines environmental measurements and a simulation of atmospheric transport of released radionuclides [13-16]. The time trend of radioactivity release of four main radionuclides xenon-133 $\left({ }^{133} \mathrm{Xe}\right),{ }^{131} \mathrm{I}$, tellurium-132 $\left({ }^{132} \mathrm{Te}\right)$ and ${ }^{137} \mathrm{Cs}$ obtained by the second method is shown in Fig. 20.1. The data for ${ }^{133} \mathrm{Xe}$ are taken from the UNSCEAR report [4], while the data for other radionuclides are taken from the recent work by Katata et al. [16]. The cumulative distribution of radionuclide release is plotted in Fig. 20.2. Xenon-133 release was completed by 


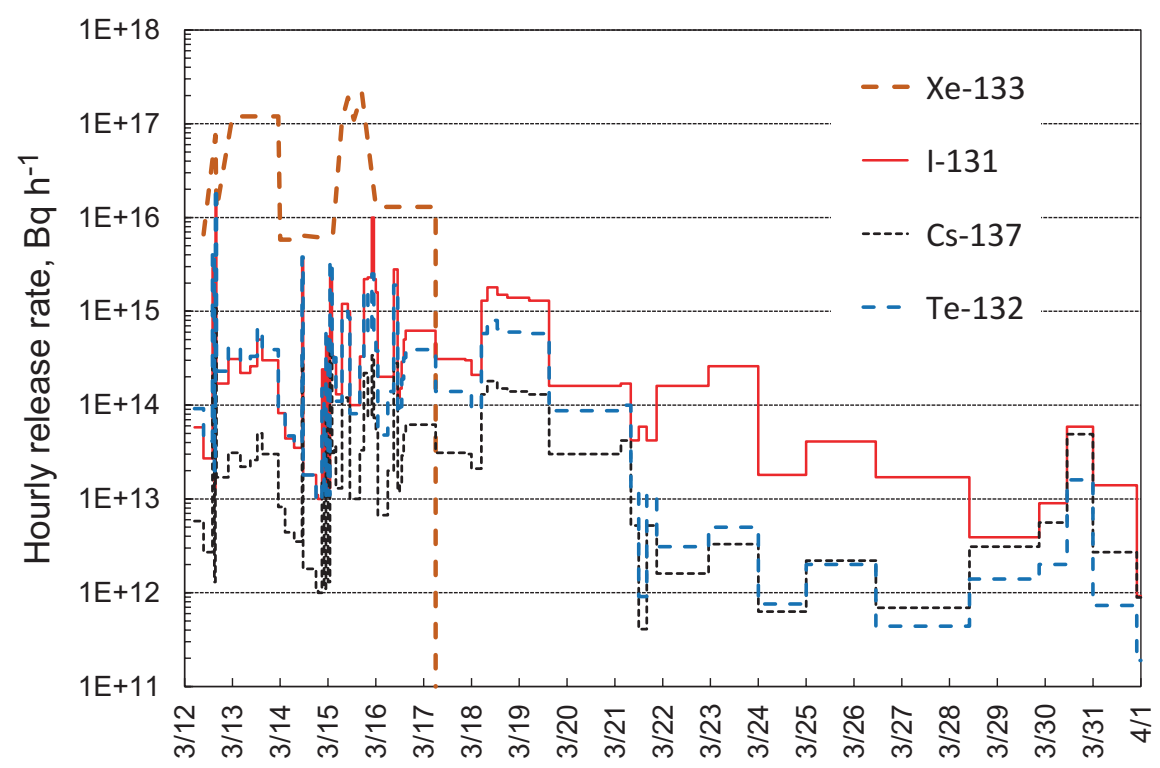

\section{March 2011}

Fig. 20.1 Hourly radioactivity release from the FNPP accident into the atmosphere during March 2011

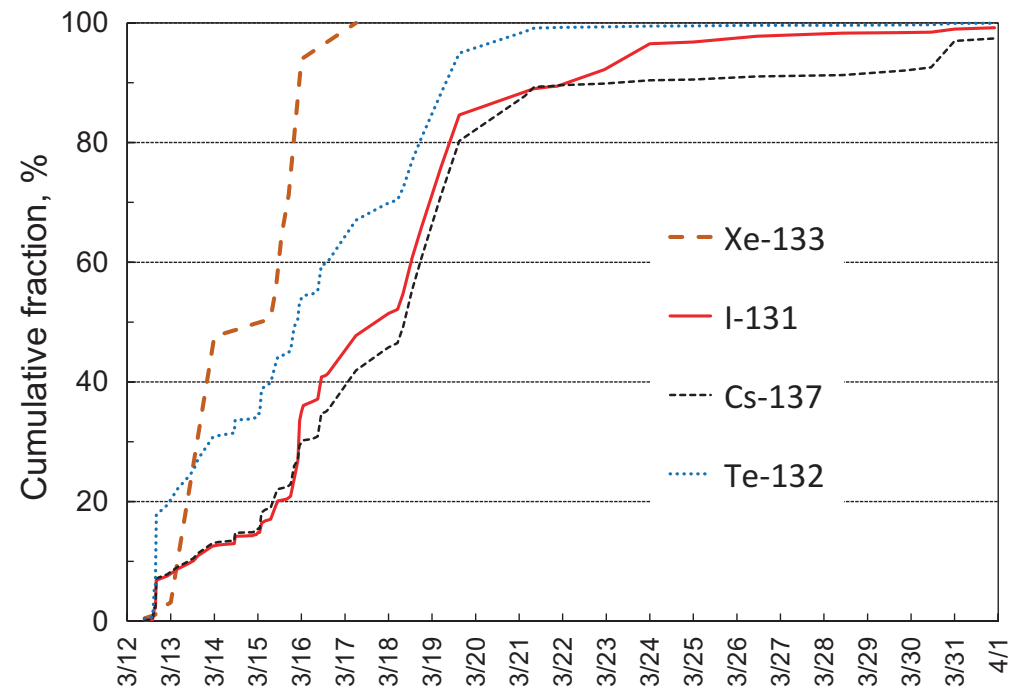

March 2011

Fig. 20.2 Cumulative distribution of radionuclide release of the FNPP accident 
Table 20.1 Comparison of the amounts of main radionuclides released into the atmosphere by the FNPP and CNPP accidents

\begin{tabular}{|c|c|c|c|c|}
\hline \multirow[b]{2}{*}{ Radionuclide } & \multicolumn{2}{|l|}{ FNPP $^{a}$} & \multicolumn{2}{|l|}{$\mathrm{CNPP}^{\mathrm{b}}$} \\
\hline & $\begin{array}{l}\text { Released } \\
\text { radioactivity, PBq }\end{array}$ & $\begin{array}{l}\text { Fraction of core } \\
\text { inventory }^{\mathrm{c}}, \%\end{array}$ & $\begin{array}{l}\text { Released radioactivity } \\
{[17], \mathrm{PBq}}\end{array}$ & $\begin{array}{l}\text { Fraction of core } \\
\text { inventory }{ }^{\mathrm{d}} \%\end{array}$ \\
\hline${ }^{133} \mathrm{Xe}$ & $10,500[4]$ & 87 & 6500 & 100 \\
\hline${ }^{131} \mathrm{I}$ & $300[16]$ & 5 & 1760 & 55 \\
\hline${ }^{132} \mathrm{Te}$ & $310[16]$ & 3.6 & 1150 & 43 \\
\hline${ }^{134} \mathrm{Cs}$ & $15[16]$ & 2.1 & 47 & 26 \\
\hline${ }^{137} \mathrm{Cs}$ & $15[16]$ & 2.1 & 85 & 30 \\
\hline${ }^{90} \mathrm{Sr}$ & $0.14[12]$ & 0.03 & 10 & 5 \\
\hline${ }^{95} \mathrm{Zr}$ & $0.017[12]$ & $2 \times 10^{-4}$ & 84 & 1.5 \\
\hline${ }^{103} \mathrm{Ru}$ & $7.5 \times 10^{-6}[12]$ & $9 \times 10^{-8}$ & 168 & 3.5 \\
\hline${ }^{106} \mathrm{Ru}$ & $2.1 \times 10^{-6}[12]$ & $9 \times 10^{-8}$ & 73 & 3.5 \\
\hline${ }^{140} \mathrm{Ba}$ & $3.2[12]$ & 0.03 & 240 & 5 \\
\hline${ }^{141} \mathrm{Ce}$ & $0.018[12]$ & $2 \times 10^{-4}$ & 84 & 1.5 \\
\hline${ }^{239} \mathrm{~Np}$ & $0.076[12]$ & $7 \times 10^{-5}$ & 400 & 1.5 \\
\hline${ }^{239} \mathrm{Pu}$ & $3.2 \times 10^{-6}[12]$ & $1 \times 10^{-4}$ & 0.013 & 1.5 \\
\hline
\end{tabular}

abecay-corrected at 14:46 on March 11, 2011

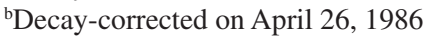

'Inventory values from Nishihara et al. [18]

${ }^{\mathrm{d} I n v e n t o r y}$ values from the Ukraine report [19]

March 17. As shown in Fig. 20.2, about $80 \%$ of the release of two important radionuclides, ${ }^{131} \mathrm{I}$ and ${ }^{137} \mathrm{Cs}$, occurred between March 15 and March 21. Radioactive materials released by two hydrogen explosions on March 12 and March 14 did not make a significant contribution to the total release.

Estimated total amounts of various radionuclides released into the atmosphere by the FNPP accident are compared with those released by the CNPP accident in Table 20.1. Xenon-133 release was greater for the FNPP accident than the CNPP accident. The released activity ratio of FNPP to CNPP for ${ }^{131} \mathrm{I}$ and ${ }^{137} \mathrm{Cs}$ is about one-sixth. Compared with the CNPP accident, very small amounts of other radionuclides such as strontium-90 $\left({ }^{90} \mathrm{Sr}\right)$, zirconium-95 $\left({ }^{95} \mathrm{Zr}\right)$, ruthenium-103 $\left({ }^{103} \mathrm{Ru}\right)$, etc. were released by the FNPP accident. These differences can be explained by the element characteristics and accident processes. Xenon-133, a rare gas radionuclide, easily escaped into the environment in both the accidents. The difference in ${ }^{133} \mathrm{Xe}$ release simply reflects the reactor power of FNPP (Units 1, 2 and 3: total $2 \mathrm{GW}$ electricity) and CNPP (Unit 4: $1 \mathrm{GW}$ ). Because the CNPP accident was a power surge accident, the explosion occurred within the reactor core and destroyed the reactor and the building at the same time. This led to direct exposure of the damaged reactor core to the atmosphere, as well as dispersion of nuclear fuels around the damaged Unit 4 building. Meanwhile, the explosions in the FNPP accident did not happen in the reactor cores. The meltdown and melt-through of reactor cores occurred inside the containment structures without direct exposure to the atmosphere. Therefore, mainly gaseous and volatile radionuclides were released into the atmosphere in case of the FNPP accident. 


\subsection{Radioactive Contamination}

The area of ${ }^{137} \mathrm{Cs}$-contaminated land is the most important factor in determining the long-term effects of nuclear accidents. The first effort to make a ${ }^{137} \mathrm{Cs}$ deposition map around FNPP was carried out by a team from the US National Nuclear Security Administration (NNSA) that arrived at the Yokota air base near Tokyo in the early morning on March 16, 2011. Beginning March 17, the team conducted an aerial measuring system (AMS) survey of radioactive contamination in the area around FNPP [20]. The results of the survey were published in their website in the autumn of 2011 [21]. Dr. Sawano, an expert on the Geographic Information System (GIS) technique, found the AMS survey results for FNPP by chance and edited the ${ }^{137} \mathrm{Cs}$ deposition map as shown in Fig. 20.3 [22]. His comparison of the ${ }^{137} \mathrm{Cs}$-contaminated area and population size for the FNPP accident and the CNPP accident is shown in Table 20.2 [23].

As seen in Table 20.2, the ${ }^{137} \mathrm{Cs}$-contaminated area was $11-15$ times larger for the CNPP accident than the FNPP accident, while the affected population living in contaminated zones defined by Chernobyl laws was only 3-5 times larger for the CNPP accident than that for the FNPP accident, reflecting a higher population density in

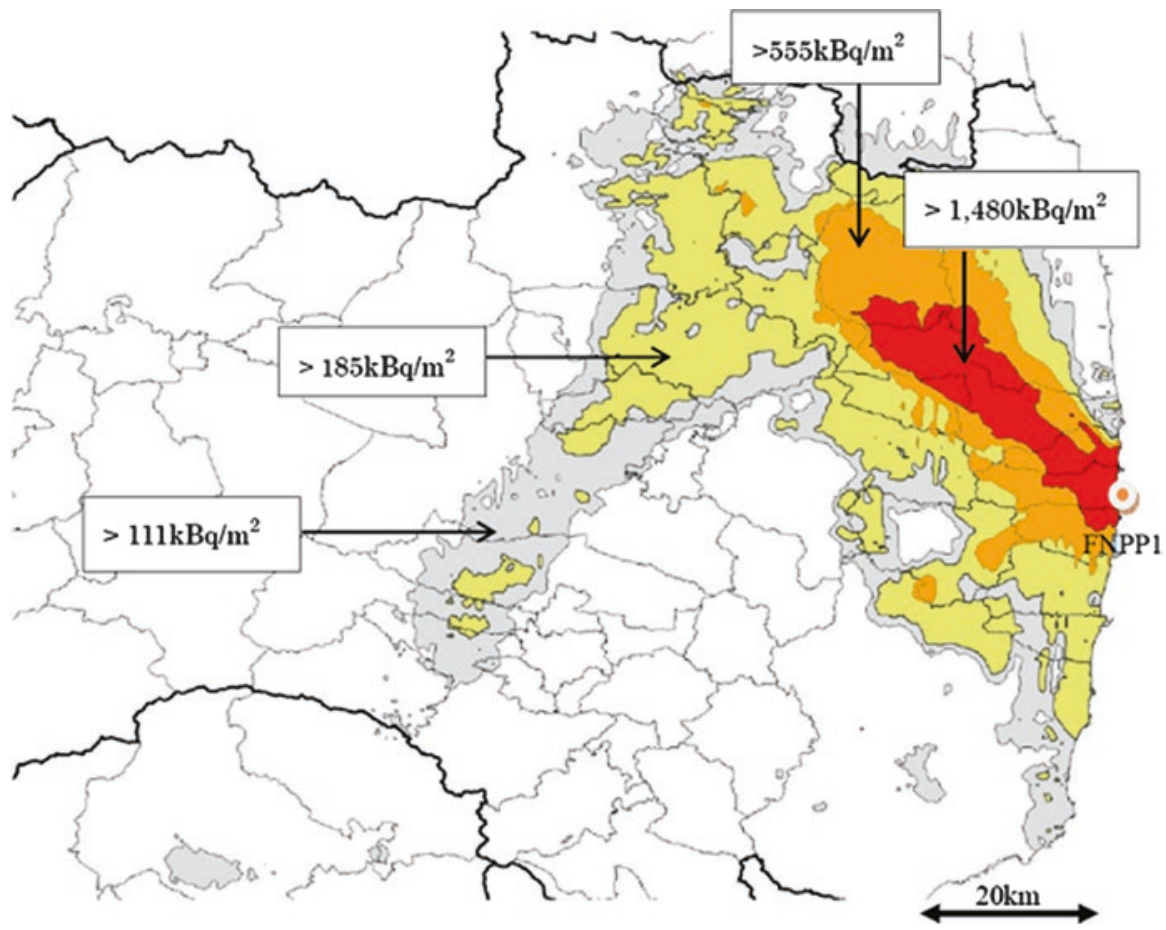

Fig. 20.3 Cesium-137 deposition map for the FNPP accident derived from DOE/NNSA AMS data following the Chernobyl classification scheme 
Table 20.2 Comparison of contaminated land area and population for the FNPP and the CNPP accidents

\begin{tabular}{|c|c|c|c|c|c|c|}
\hline & \multicolumn{6}{|c|}{ Zone classification in CNPP by ${ }^{137}$ Cs contamination level ${ }^{\mathrm{a}}$} \\
\hline & \multicolumn{2}{|c|}{ (First zone) } & \multicolumn{2}{|c|}{ (Second zone) } & \multicolumn{2}{|c|}{ (Third zone) } \\
\hline & \multicolumn{2}{|c|}{$>1480 \mathrm{kBq} \mathrm{m}^{-2}$} & \multicolumn{2}{|c|}{$555-1480 \mathrm{kBq} \mathrm{m}^{-2}$} & \multicolumn{2}{|c|}{$185-555 \mathrm{kBq} \mathrm{m}^{-2}$} \\
\hline & $\begin{array}{l}\text { Area, } \\
\mathrm{km}^{2}\end{array}$ & $\begin{array}{l}\text { Population, } \\
\text { persons }\end{array}$ & $\begin{array}{l}\text { Area, } \\
\mathrm{km}^{2}\end{array}$ & $\begin{array}{l}\text { Population, } \\
\text { persons }\end{array}$ & $\begin{array}{l}\text { Area, } \\
\mathrm{km}^{2}\end{array}$ & $\begin{array}{l}\text { Population, } \\
\text { persons }\end{array}$ \\
\hline FNPP & 272 & 30,159 & 495 & 52,157 & 1405 & 261,076 \\
\hline CNPP & 3100 & $149,000^{\mathrm{b}}$ & 7200 & 235,000 & 19,120 & 689,000 \\
\hline $\begin{array}{l}\text { CNPP/FNPP } \\
\text { ratio }\end{array}$ & 11.4 & 4.9 & 14.5 & 4.5 & 13.6 & 2.6 \\
\hline
\end{tabular}

${ }^{a}$ According to the Chernobyl laws in Ukraine, Belarus and Russia, first zone, second zone and third zone correspond to areas of alienation, obligatory resettlement and voluntarily resettlement, respectively [23]

${ }^{\mathrm{b}}$ This number includes 116,000 persons who were evacuated from the $30 \mathrm{~km}$ zone just after the accident in 1986

Table 20.3 Relative deposition ratios of radionuclides $\left({ }^{137} \mathrm{Cs}=1\right)$, contributing $\gamma$-ray exposure $1 \mathrm{~m}$ above ground $[6,7]$

\begin{tabular}{l|l|l|l|l}
\hline \multirow{2}{*}{ Radionuclide } & & \multirow{2}{*}{$\begin{array}{l}\text { Exposure rate conversion } \\
\text { factor }\left(\mathrm{ny} \mathrm{h}^{-1}\right) /\left(\mathrm{kBq} \mathrm{m}^{-2}\right)\end{array}$} & \multicolumn{3}{|l}{ Relative deposition ratio to ${ }^{137} \mathrm{Cs}$} \\
\cline { 5 - 6 } & Half-life & FNPP & CNPP \\
\hline${ }^{95} \mathrm{Zr}$ & 65.5 days & 2.82 & - & 20 \\
\hline${ }^{95} \mathrm{Nb}$ & 35.0 days & 2.92 & - & 20 \\
\hline${ }^{103} \mathrm{Ru}$ & 39.3 days & 1.85 & - & 16 \\
\hline${ }^{131} \mathrm{I}$ & 8.04 days & 1.49 & 11.5 & 18 \\
\hline${ }^{132} \mathrm{Te}$ & 3.25 days & 0.79 & 8 & 28 \\
\hline${ }^{132} \mathrm{I}$ & $(2.30 \mathrm{~h})^{\mathrm{a}}$ & 8.61 & 8 & 28 \\
\hline${ }^{134} \mathrm{Cs}$ & 2.07 years & 5.97 & 1 & 0.4 \\
\hline${ }^{137} \mathrm{Cs}$ & 30.1 years & 2.18 & 1 & 1 \\
\hline${ }^{140} \mathrm{Ba}$ & 12.8 days & 0.57 & - & 22 \\
\hline${ }^{140} \mathrm{La}$ & $(1.68 \text { days })^{\mathrm{a}}$ & 7.83 & - & 11 \\
\hline${ }^{239} \mathrm{~Np}$ & 2.36 days & 0.60 & - & 120 \\
\hline
\end{tabular}

${ }^{a}$ These radionuclides are treated at radioactive equilibrium with parent radionuclides

the latter. Another difference is that the east side of FNPP is surrounded by the Pacific Ocean, and the wind direction over the Japanese islands is predominantly to the east. Therefore, radionuclides were more likely to deposit in the Pacific Ocean than on land.

Gamma-ray exposure rates above the contaminated ground were calculated assuming the radionuclide composition both for the FNPP and the CNPP accidents. The deposited amounts of radionuclides contributing $\gamma$-ray exposure were shown in Table 20.3 as values of relative deposition ratio to ${ }^{137} \mathrm{Cs}[6,7]$. Deposition was assumed to occur at a time on April 26, 1986, the day of the accident for CNPP and on March 15, 2011, the day when the most severe contamination occurred for FNPP. Figure 20.4a shows the temporal change in the $\gamma$-ray exposure rate $1 \mathrm{~m}$ above 

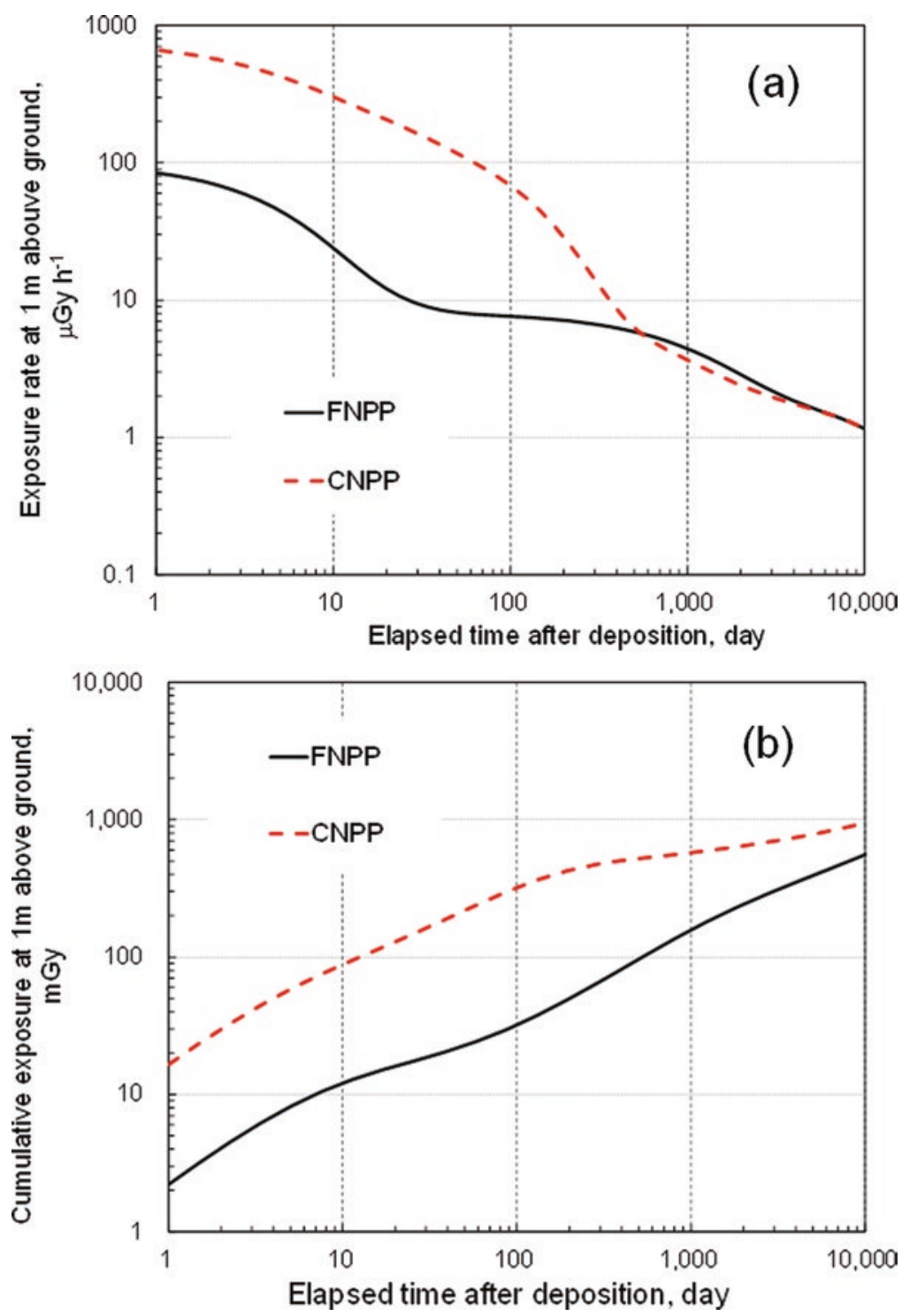

Fig. 20.4 (a) Radiation exposure rate, $\mu \mathrm{Gy} \mathrm{h}^{-1}$ and (b) cumulative exposure, $\mathrm{mGy}$, at $1 \mathrm{~m}$ above ground normalized to the initial ${ }^{137} \mathrm{Cs}$ deposition of $1 \mathrm{MBq} \mathrm{m}^{-2}$

ground normalized to the initial ${ }^{137} \mathrm{Cs}$ deposition of $1 \mathrm{MBq} \mathrm{m}^{-2}$ for both the FNPP and the CNPP accidents. The initial exposure rate 1 day after deposition was $80 \mu \mathrm{Gy}$ $\mathrm{h}^{-1}$ for the FNPP accident, while it was $700 \mu \mathrm{Gy} \mathrm{h}^{-1}$ for the CNPP accident (nine times larger). Given the radionuclide compositions in Table 20.2, such radionuclides as ${ }^{95} \mathrm{Zr},{ }^{103} \mathrm{Ru},{ }^{140} \mathrm{Ba}$ and ${ }^{239} \mathrm{~Np}$ have a substantial contribution to radiation exposure during the 1 st year after the CNPP accident. Two months after deposition, 
radiocesiums ${ }^{134} \mathrm{Cs}$ and ${ }^{137} \mathrm{Cs}$ accounted for $99 \%$ of the radiation exposure rate in the FNPP accident, while the contribution of radiocesiums in the CNPP accident was only $4 \%$ of the exposure rate at the same time [6]. Interestingly, the FNPP exposure rate exceeded CNPP approximately 1.5 years after deposition and was almost the same after 10 years (Fig. 20.4a). This exposure rate trend is created by differences in the deposition ratio of ${ }^{134} \mathrm{Cs}$ (half-life: 2.07 years) to ${ }^{137} \mathrm{Cs}$ (half-life: 30.1 years) for the FNPP accident $\left({ }^{134} \mathrm{Cs}:{ }^{137} \mathrm{Cs}=1: 1\right)$ and the CNPP accident $\left({ }^{134} \mathrm{Cs}:{ }^{137} \mathrm{Cs}=0.5: 1\right)$.

Cumulative exposures $1 \mathrm{~m}$ above ground normalized to the initial ${ }^{137} \mathrm{Cs}$ deposition of $1 \mathrm{MBq} \mathrm{m}^{-2}$ were plotted both for the FNPP and the CNPP accidents (Fig. 20.4b). Cumulative exposures after the 1st year were $63 \mathrm{mGy}$ and $500 \mathrm{mGy}$ for the FNPP and the CNPP accident, respectively. Cumulative exposures at 30 years are $500 \mathrm{mGy}$ and $970 \mathrm{mGy}$ for the FNPP and the CNPP accident, respectively. The contribution of radiocesiums to the cumulative exposure for the 1st year was $83 \%$ for FNPP and $7.4 \%$ for CNPP, and at 30 years it is $98 \%$ for FNPP and $84 \%$ for CNPP. Therefore, different compositions of ground contamination between the FNPP accident and the CNPP accident led to different patterns of radiation exposure, primarily during the 1 st year.

\subsection{Conclusion}

Although both the FNPP accident and the CNPP accident are classified as Level 7, the worst nuclear incidence classification of the INES by IAEA, there are various differences between the accidents. These differences include the accident process, released radionuclide composition and meteorological and geological conditions. Cesium-137 is the most important radionuclide to consider due to its long-term effects. The amount of ${ }^{137} \mathrm{Cs}$ released by the FNPP accident is estimated to be about six times smaller compared to the CNPP accident. The ${ }^{137} \mathrm{Cs}$-contaminated land area is 11-15 times smaller for the FNPP accident compared to the CNPP accident. Cumulative radiation exposure for 1 year above ground at the same level of ${ }^{137} \mathrm{Cs}$ contamination is about eight times smaller for the FNPP accident compared to the CNPP accident, while it decreases to about two times for 30 years, reflecting the different radionuclide composition of ground deposition.

\section{References}

1. IAEA (2013) INES: the international nuclear and radiological event scale. User's Manual 2008 Edition. IAEA. https://www-pub.iaea.org/MTCD/Publications/PDF/INES2013web.pdf. Accessed 15 Apr 2018

2. METI (2011) METI news release. April 12, 2011. http://warp.ndl.go.jp/info:ndljp/pid/3514506/ www.nisa.meti.go.jp/english/files/en20110412-4.pdf. Accessed 15 Apr 2018

3. NAIIC (2012) The official report of The Fukushima Nuclear Accident Independent Investigation Commission. http://warp.da.ndl.go.jp/info:ndljp/pid/3856371/naiic.go.jp/en/report/. Accessed 15 Apr 2018 
4. UNSCEAR (2014) Levels and effects of radiation exposure due to the nuclear accident after the 2011 great east-Japan earthquake and tsunami. Annex A of UNSCEAR 2013 Report. http:// www.unscear.org/docs/reports/2013/13-85418_Report_2013_Annex_A.pdf. Accessed 15 Apr 2018

5. IAEA (2015) The Fukushima Daiichi accident. Report by the Director General. IAEA. 2015. https://www-pub.iaea.org/books/IAEABooks/10962/The-Fukushima-Daiichi-Accident. Accessed 15 Apr 2018

6. Imanaka T, Hayashi G, Endo S (2015) Comparison of the accident process, radioactivity release and ground contamination between Chernobyl and Fukushima-1. J Radiat Res 56(suppl):i56i61. https://doi.org/10.1093/jrr/rrv074. Accessed 15 Apr 2018

7. Imanaka $T$ (2017) Fukushima-1 and Chernobyl: comparison of radioactivity release and contamination. In: Korogodina VL et al (eds) Genetics, evolution and radiation. Hidelberg. Springer, p 225-236

8. Nuclear Emergency Response Headquarter of Japanese Government (2011) Report of Japanese Government to the IAEA ministerial conference on nuclear safety - the accident at TEPCO's Fukushima Nuclear Power Stations. http://www.japan.kantei.go.jp/kan/topics/201106/iaea houkokusho_e.html. Accessed 15 Apr 2018

9. TEPCO (2011) Fukushima nuclear accident analysis report: interim report. December 2, 2011. http://www.tepco.co.jp/en/press/corp-com/release/betu11_e/images/111202e14.pdf. Accessed 15 Apr 2018

10. Atomic Energy Society of Japan (2014) The Fukushima Daiichi nuclear accident: final report of the AESJ Investigation Committee. Hidelberg. Springer

11. JNES (2011) A tentative report on the progression and status of the accident at the Fukushima Dai-ichi Nuclear Power Station. Tokyo. Japan Nuclear Energy Safety Organization. (in Japanese)

12. NISA (2011) Report on the situation of reactor core of Unit-1, -2 and 3 of FDNPP. (in Japanese) http://dl.ndl.go.jp/view/download/digidepo_6017222_po_20110606-1nisa.pdf?contentNo=1. Accessed 15 Apr 2018

13. Chino M, Nakayama $\mathrm{H}$, Nagai $\mathrm{H}$ et al (2011) Preliminary estimation of release amounts of 131I and 137Cs accidentally discharged from Fukushima Daiichi Nuclear Power Plant into the atmosphere. J Nucl Sci Technol 48:1129-1134

14. Stohl A, Siebert P, Wotawa G et al (2012) Xenon-133 and caesium-137 releases into the atmosphere from the Fukushima Dai-ichi nuclear power plant: determination of the source term, atmospheric dispersion, and deposition. Atmos Chem Phys 12:2313-2343. https://doi. org/10.5194/acp-12-2313-2012

15. Terada H, Katata G, Chino $\mathrm{H}$ et al (2012) Atmospheric discharge and dispersion of radionuclides during the Fukushima Dai-ichi Nuclear Power Plant Accident. Part II: verification of the source term and analysis of regional-scale atmospheric dispersion. J Environ Radioact 112:141-154

16. Katata G, Chino M et al (2015) Detailed source term estimation of the atmospheric release for the Fukushima Daiichi Nuclear Power Station accident by coupling simulations of an atmospheric dispersion model with an improved deposition scheme and oceanic dispersion model. Atmos Chem Phys 15:1029-1070. https://doi.org/10.5194/acp-15-1029-2015

17. Chernobyl Forum (2005) Environmental consequences of the Chernobyl accident and their remediation: twenty years of experience. Report of the UN Chernobyl Forum Expert Group "Environment" (EGE), IAEA. http://www-ns.iaea.org/downloads/rw/meetings/environ-consequences-report-wm-08.05.pdf. Accessed 15 Apr 2018

18. Nishihara K, Iwamoto H, Suyama K (2012) Estimation of fuel compositions in FukushimaDaiichi Nuclear Power Plant. JAEA-Data/Code 2012-018. https://jopss.jaea.go.jp/pdfdata/ JAEA-Data-Code-2012-018.pdf. Accessed 15 Apr 2018

19. MinChernobyl (1996) Ten years after the accident at Chernobyl NPP: national report of Ukraine. (in Russian) 
20. Lyons C, Colton D (2012) Aerial measuring system in Japan. Health Phys 102:509-515

21. US DOE/NNSA (2011) US DOE/NNSA response to 2011 Fukushima incident: raw aerial data and extracted ground exposure rates and cesium deposition. http://catalog.data.gov/dataset/usdoe-nnsa-response-to-2011-fukushima-incident-raw-aerial-data-and-extracted-ground-expos20e73. Accessed 15 Apr 2018

22. Sawano N (2013) Really useful contamination map. Shueisha, Tokyo. (in Japanese)

23. Sawano N (2017) Mapping and analysis of ${ }^{137} \mathrm{Cs}$ ground contamination due to the FNPP accident using US NNSA AMS data. Kagaku 87:294-301. in Japanese

Open Access This chapter is licensed under the terms of the Creative Commons Attribution 4.0 International License (http://creativecommons.org/licenses/by/4.0/), which permits use, sharing, adaptation, distribution and reproduction in any medium or format, as long as you give appropriate credit to the original author(s) and the source, provide a link to the Creative Commons license and indicate if changes were made.

The images or other third party material in this chapter are included in the chapter's Creative Commons license, unless indicated otherwise in a credit line to the material. If material is not included in the chapter's Creative Commons license and your intended use is not permitted by statutory regulation or exceeds the permitted use, you will need to obtain permission directly from the copyright holder.

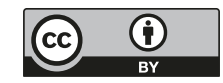

